\title{
Navigation training requirements and technical support for the Danube Inland Navigation Simulator
}

\author{
Martin JURKOVIČ ${ }^{1, a}$ and Andrej DÁVID ${ }^{1, b}$ \\ ${ }^{1}$ University of Žilina in Žilina, The Faculty of Operation and Economics of Transport and \\ Communications, Department of Water Transport, Univerzitná 1 Žilina, 010 26, Slovakia \\ amartin.jurkovic@fpedas.uniza.sk, ${ }^{\mathrm{b}}$ andrej.david@fpedas.uniza.sk
}

\begin{abstract}
Keywords: Navigation Simulator, training requirements, Simulator Centre, manoeuvring,
\end{abstract} infrastructure

\begin{abstract}
In our study we describe the navigation training requirements for simulator training, and analysing the suggested infrastructure of an inland navigation simulator training centre. Intensity of navigation training on the Inland Navigation Simulator depends on its character and the chosen difficulty (complexity). The participant of the navigation training has to be able to carry out the minimum training skills depending on the difficulty. The level of difficulty could be divided according to the education target like: basic trainings for non-professionals, medium level trainings for crew on operational level, high level training for crew on management level ( + practicing Local Knowledge Requirements (LKR) if possible).
\end{abstract}

\section{Introduction}

To become a crew member of the vessel on the inland waterways obtain to complete education and training process. Especially practical training process is different within the EU. It is necessary to find the ways towards unification of the education and training process in the field of inland water transport. The authorities, education institutions and national stakeholders along the Danube and within the EU are interested in the implementation of Danube Navigation Simulator training into the educational process. It is necessary to define the basic navigation training requirements on the simulator.

This study was elaborated in accordance with the requirements of the Danube and Rhine Commission focused on the harmonization of the educational and training process of crew member in the field of inland water transport. It is the part of the international project HINT (Harmonized Inland Navigation Transport through education and information technology). The basis of this study was the investigation of the navigation training requirements on the Danube Navigation Simulator conducted in the Danube region. [1]

\section{Navigation training requirements}

The definition of the navigation training requirements is necessary to ensure safety navigation along the Danube waterway. It has to be done in accordance with the European Code for Inland Waterways (CEVNI). The most important part of the training on the Danube Navigation Simulator is manoeuvring. However, it is a broad term, it is necessary to briefly specify the particular activity. [2]

Intensity of navigation training on the Inland Navigation Simulator depends on its character and chosen difficulty (complexity). The participants of the navigation training have to be able to carry out the minimum training skills depending on the difficulty. The level of difficulty could be divided according to the education target like:

- basic trainings for non-professionals,

- medium level trainings for crew on operational level,

- high level training for crew on management level (+ practicing LKR if possible). [1] 
Table 1 Navigation training requirements depending on the level of difficulty

\begin{tabular}{|c|c|c|c|}
\hline Skills & Basic trainings & Medium level trainings & High level trainings \\
\hline $\begin{array}{c}\text { Specific } \\
\text { manoeuvres }\end{array}$ & $\begin{array}{l}\text { Basic manoeuvres in } \\
\text { calm water, navigation } \\
\text { in confluence of the } \\
\text { rivers, overtaking and } \\
\text { passing the vessels, } \\
\text { turnover of the vessel } \\
\text { in calm water, turnover } \\
\text { of the vessel } \\
\text { upstream/downstream, } \\
\text { navigation in the river } \\
\text { arch, navigation } \\
\text { through the narrows }\end{array}$ & $\begin{array}{l}\text { Basic manoeuvres in calm } \\
\text { water, navigation in } \\
\text { confluence of the rivers, } \\
\text { overtaking and passing the } \\
\text { vessels, turnover of the } \\
\text { vessel in calm water, } \\
\text { turnover of the vessel } \\
\text { upstream/downstream, } \\
\text { navigation in the river arch } \\
\text { with bearing, navigation } \\
\text { through the narrows with } \\
\text { managing traffic, } \\
\text { navigation under the } \\
\text { bridges in two- way traffic, } \\
\text { navigation in the shallows, } \\
\text { enter to the port basin, exit } \\
\text { from the port basin, } \\
\text { navigation in ice. }\end{array}$ & $\begin{array}{l}\text { Basic manoeuvres in calm water, } \\
\text { navigation in confluence of the rivers, } \\
\text { overtaking and passing the vessels, } \\
\text { turnover of the vessel in calm water, } \\
\text { turnover of the vessel } \\
\text { upstream/downstream, navigation in the } \\
\text { river arch with bearing, navigation } \\
\text { through the narrows with managing } \\
\text { traffic, navigation under the bridges with } \\
\text { two- way traffic, navigation in the } \\
\text { shallows, enter to the port basin, exit } \\
\text { from the port basin, navigation in ice. }\end{array}$ \\
\hline $\begin{array}{c}\text { Convoy set } \\
\text { up }\end{array}$ & $\begin{array}{l}\text { Set up the emergency } \\
\text { towed convoy with } \\
\text { secure and fasten a } \\
\text { towed rope. }\end{array}$ & $\begin{array}{l}\text { Manoeuvring process with } \\
\text { vessel focused on } \\
\text { combining/untying of the } \\
\text { boats to the required } \\
\text { convoy }\end{array}$ & $\begin{array}{l}\text { Manoeuvring process with a tug boat in } \\
\text { the particular river place focused on the } \\
\text { combining/untying of the tug boats to the } \\
\text { required convoy }\end{array}$ \\
\hline $\begin{array}{l}\text { Emergency } \\
\text { situation }\end{array}$ & $\begin{array}{l}\text { Stopping and anchoring } \\
\text { of the vessel with a } \\
\text { main engine broken. } \\
\text { Manoeuvre in the case } \\
\text { of "man overboard". }\end{array}$ & $\begin{array}{l}\text { Towing the motor cargo } \\
\text { vessel by another vessel } \\
\text { upstream/downstream. } \\
\text { Managing the motor cargo } \\
\text { vessel without engine } \\
\text { upstream/downstream. } \\
\text { Managing the vessel/tug } \\
\text { boat with broken steering } \\
\text { control for the possibilities } \\
\text { of emergency stopping. } \\
\text { Manoeuvre in the case of } \\
\text { "man overboard". }\end{array}$ & $\begin{array}{l}\text { Manoeuvring of the vessel with engine } \\
\text { failure. Manoeuvring of the vessel in the } \\
\text { loss of control (rudder/nozzle) and } \\
\text { stopping the vessel on the waterway. } \\
\text { Manoeuvre in the case of "man } \\
\text { overboard". }\end{array}$ \\
\hline
\end{tabular}

Source: Authors

Table 2 Navigation training requirements for all levels of difficulty

\begin{tabular}{|c|c|c|}
\hline Skills & For all levels & Additional points \\
\hline $\begin{array}{c}\text { Navigation in } \\
\text { different } \\
\text { weather } \\
\text { conditions }\end{array}$ & $\begin{array}{c}\text { Navigation in clear weather, daylight, } \\
\text { dawn/dusk, fog, night conditions, restricted } \\
\text { visibility, rain, snow. Navigation under the } \\
\text { effect of current and wind. Navigation with } \\
\text { appropriate navigation devices. }\end{array}$ & \\
\hline $\begin{array}{c}\text { Navigation in } \\
\text { different types } \\
\text { of waterways }\end{array}$ & $\begin{array}{c}\text { Navigation in canal and regulated river, in } \\
\text { different water levels, in shallows. } \\
\text { Participants must be able to analyse the } \\
\text { particular river section individually and must } \\
\text { be able to adapt navigation to real } \\
\text { conditions. Navigation under the bridges } \\
\text { must be evaluated individually for each } \\
\text { under passing. Navigation in both directions } \\
\text { with other vessels with application of } \\
\text { CEVNI for different navigation situation. }\end{array}$ & \\
& $\begin{array}{c}\text { Defining approximately } 3 \\
\text { representative water levels and } \\
\text { waterways (canals, rivers, lakes) }\end{array}$ & \\
& \\
& & \\
& & \\
\end{tabular}




\begin{tabular}{|c|c|c|}
\hline $\begin{array}{l}\text { Navigation and } \\
\text { communication } \\
\text { events }\end{array}$ & $\begin{array}{l}\text { Using radar, I-ECDIS, inland AIS, } \\
\text { VHF/UHF radio devices, auto pilot, light } \\
\text { controls, engine controls, indicators, alarms, } \\
\text { internal communication devices and signals, } \\
\text { bow thruster controls. }\end{array}$ & $\begin{array}{l}\text { Participants must be able to } \\
\text { communicate with other vessels, } \\
\text { traffic controls, authorities, customs, } \\
\text { lock operators. }\end{array}$ \\
\hline Anchoring & $\begin{array}{l}\text { Participants must be able to manage } \\
\text { anchoring with a bow anchor (front and } \\
\text { rear), a stern anchor; using anchor controls } \\
\text { (voice, lights), responding to the impacts of } \\
\text { anchoring the vessel, anchoring under the } \\
\text { influences of stream and wind. Turnover of } \\
\text { the vessel by an anchor. }\end{array}$ & \\
\hline Locking & $\begin{array}{l}\text { Participants must be able to pass through a } \\
\text { lock, sort a convoy, disconnect and connect } \\
\text { convoy necessary for locking, moor the } \\
\text { vessel. VHF communication with the lock } \\
\text { according to the procedural process. } \\
\text { Manoeuvring in front of and behind the lock } \\
\text { (without the wind influences) with the } \\
\text { assistance of the pilot on UHF. Entering the } \\
\text { lock simultaneously with other vessels, } \\
\text { positioning to the wall of the lock and side } \\
\text { mooring, close the lock (filling or releasing } \\
\text { of the lock), exit from the lock with the } \\
\text { front-side or back side wind influences, } \\
\text { manoeuvring in reduced visibility during the } \\
\text { day or at night. }\end{array}$ & $\begin{array}{l}\text { Maintaining the manoeuvrability of } \\
\text { the vessel at the nominal momentum, } \\
\text { Stopping the vessel on the accurately } \\
\text { determined place of the lock, } \\
\text { entering the commands for mooring } \\
\text { to the staff. }\end{array}$ \\
\hline Mooring & $\begin{array}{l}\text { Participants must be aware of the speed } \\
\text { influences of mooring and must be able to } \\
\text { adjust the speed of the vessel before and } \\
\text { after mooring depending of individual } \\
\text { conditions. Participants must be able to } \\
\text { manage longitudinal and transverse mooring } \\
\text { and use a bow thruster. Mooring to the } \\
\text { different kinds of the pontoon. }\end{array}$ & $\begin{array}{l}\text { Participant must adjust speed when } \\
\text { the vessel is passing near other } \\
\text { moored vessels. }\end{array}$ \\
\hline Skills & For all levels & Additional points \\
\hline Others & $\begin{array}{l}\text { Participant must be aware of the height of } \\
\text { the ship, based on actual water level for a } \\
\text { safe navigation under the bridges, electrical } \\
\text { cables, etc. Participant must be familiar with } \\
\text { individual rules and regulations of } \\
\text { navigation depending of particular river } \\
\text { section. }\end{array}$ & $\begin{array}{l}\text { Simulator must be able to indicate } \\
\text { dangerous or inappropriate } \\
\text { navigation with light and sounds } \\
\text { controls. }\end{array}$ \\
\hline
\end{tabular}

Source: Authors

\section{Technical devices on inland navigation simulator}

Managing workplace of the inland vessel is a wheelhouse and an engine room. It is necessary to simulate the vessel from the wheelhouse for the Danube navigation simulator. The wheelhouse contains navigation and communication technologies. From the wheelhouse it is managed the movement of the vessel and other important technical facilities in order to ensure navigational safety. The part of the wheelhouse is also the control panel indicating the functionality of all 
important navigation equipment. The spatial arrangement of the wheelhouse, navigation equipment and their location are according to:

- $\quad$ EU Directive 87/2006,

- European Commission Decision 61/2006 for EU (ECE/TRANS/SC/.3/172),

- Danube Commission document published in 2007 (DC/CEC 68/7).

The layout of the wheelhouse, instruments, consoles, communication equipment and other indicators have to be done in accordance with these regulations. [4]

\section{Radar}

Type: River radar approved for navigation on the Danube.

Composition of device: Radar display, controls.

Technical design of the radar: radar display + functional maquette of the radar controls or electronic counter/board with controls in accordance with technical requirements for the radar and simplicity of managing with radar controls.

Object of simulation:

- visualisation of the objects in the vicinity of the vessel on the radar screen, which are visible from the vessel during navigation,

- active start-up of the radar, setting, tuning and amplification of the radar picture focusing on the reflections from the objects/targets,

- adjustability of the radar range to the corresponding visualisation on the radar screen,

- active functionality of VRM, EBL, navigation line with corresponding visualisation of indicated data on the radar screen,

- active functionality of switching between the display orientation $\mathrm{N} \leftrightarrow$ course with the corresponding visualisation on the radar screen and the axis of the vessel,

- active visualisation of indicated data by the appended nautical instruments,

- visualisation of the objects without reflectors, with reflectors and all vessels,

- visualisation of disturbing effects misrepresenting the radar visualisation of the inland waterways and its removal/reduction,

- active indication of the speed of angular rotation of the vessel in accordance with the specified movement of the vessel,

- rudder angle indicator,

- visualization of the radar image on the I-ECDIS base.

Table 3 Requirements of radar simulation on different simulator level

\begin{tabular}{|c|c|c|c|}
\hline Level of simulator & low & middle & high \\
\hline Basic operation of the radar with its visualisation & $\mathrm{x}$ & $\mathrm{x}$ & $\mathrm{x}$ \\
\hline $\begin{array}{l}\text { Radar visualisation with disturbing hydrological and meteorological } \\
\text { influences. }\end{array}$ & & $\mathrm{x}$ & $\mathrm{x}$ \\
\hline $\begin{array}{l}\text { Radar visualisation with the disturbing influences of the objects (fixed } \\
\text { and in motion). }\end{array}$ & & $\mathrm{x}$ & $\mathrm{x}$ \\
\hline Visualisation of indicated data from the nautical devices (AIS, Lot) & & & $\mathrm{x}$ \\
\hline Radar visualisation on the base of ENC & & & $\mathrm{x}$ \\
\hline
\end{tabular}

Source: Authors

\section{I-ECDIS}

Type of display device for ENC:

- approved type of PC for on-board operation on inland waterways,

- approved software for visualisation of ENC maps,

- ENC with database of difficult river sections in standardized format of I-ECDIS. 
Composition of device: PC with keyboard, visualisation software, database of ENC on portable device.

Object of simulation:

- commissioning and download updated database of dynamic data,

- display of selected river sections of navigation on the ENC in I-ECDIS format,

- interim position of the vessel on the map scanned from the AIS device,

- dynamic change of depth depending on the inserted height of the water level according to the particular watermark,

- route planning of the vessel,

- records itinerary of the vessel - navigation history.

\section{AIS (Simulated AIS information, device errors)}

Type of device: Approved for vessel navigation within RIS and for AIS inland waterways.

Composition of device:

- functional maquette of the device; receiving - transmitting data; output of the relevant position point, course, speed of the vessel, connection to the radar and PC with ENC.

Object of simulation:

- commissioning and entering the basic data of the vessel,

- ability to view other vessels on the screen with relevant data through the device/program menu,

- call and retrieve data of the water level and NtS messages,

- receiving and sending urgent messages.

\section{VHF Radio}

Type of device: approved for navigation on the Danube.

Composition of device: functional maquette with controls including microphone.

Object of simulation:

- commissioning for receiving and transmitting,

- selectivity of channels or frequencies for VHF connection,

- simplex operation, duplex operation,

- disturbing effects and tunability,

- voice communication on selected channels.

Table 4 Requirements of VHF radio simulation on different simulator levels

\begin{tabular}{|c|c|c|c|}
\hline Level of simulator & low & middle & high \\
\hline Basic functional managing for receiving and transmitting & $\mathrm{x}$ & $\mathrm{x}$ & $\mathrm{x}$ \\
\hline Operation in simplex regime & $\mathrm{X}$ & $\mathrm{X}$ & $\mathrm{X}$ \\
\hline Operation in duplex regime & & $\mathrm{X}$ & $\mathrm{x}$ \\
\hline Disturbing influences and tunability in interaction ship-ship & $\mathrm{x}$ & $\mathrm{X}$ & $\mathrm{x}$ \\
\hline Disturbing influences and tunability without interaction ship-ship & & $\mathrm{X}$ & $\mathrm{x}$ \\
\hline
\end{tabular}

Source: Author

\section{Echo-sounder}

Type of device: approved for navigation on the Danube.

Composition of device: functional maquette with controls and indication of depth; output for radar.

Object of simulation:

- measured depth under the vessel corresponding with a real position of the vessel on the specific section of the waterways according AIS and on the stretch of ENC. 


\section{Rate of turn indicator}

Type of device: approved for navigation on the Danube.

Composition of device: functional maquette with managing controls.

Object of simulation:

- corresponding rotation of the vessel depending on the rudder deflection, bow thruster, vessel speed, displacement, draft, vessel dimension and the effect of external influences.

\section{Summary}

Navigation simulator technology is a valuable training tool. It can be used by licensed boatmen for ongoing professional development. When it is used with on-board and ship model training, it can also be very helpful for the students and apprentices wishing to become a crew member on the vessel. The simulator provides training in many navigation techniques (navigation of the vessel in restricted waters, dealing with emergency situation, using navigational aids etc.). It is necessary to make an effort directed towards the harmonization of the education and training process of crew member within the EU. The implementation of the training on the inland navigation simulator could be a tool how to achieve these goals.

\section{References}

[1] A. Dávid, J. Šlesinger, M. Jurkovič, C. Hargitai, D. György, G. Simongáti: Danube Navigation Requirements and Concept, Zilina, Budapest, September 2014.

[2] Z. Dvořák, B. Leitner \& L. Novák, (2011),. National Transport Information System in Slovakia as a Tool for Security Enhancing of Critical Accident Locations. Kaunas, Lithuania, Kaunas University of Technology. 2011. p. 145-148, ISSN 1822-296X.

[3] Danube Commission document published in 2007 (DC/CEC 68/7).

[4] European Commission Decision 61/2006 for EU (ECE/TRANS/SC/.3/172).

[5] http://www.hintproject.net/getpage.php?page=about.php. Accessed: 2014-05-01. 